\title{
The elephant in the Room
}

Citation for published version (APA):

Olaerts, M. (2017). The elephant in the Room: Over verbondenheid, macht en belangenafweging in het ondernemingsrecht. Maastricht University. https://doi.org/10.26481/spe.20170915mo

Document status and date:

Published: 15/09/2017

DOI:

10.26481/spe.20170915mo

Document Version:

Publisher's PDF, also known as Version of record

\section{Please check the document version of this publication:}

- A submitted manuscript is the version of the article upon submission and before peer-review. There can be important differences between the submitted version and the official published version of record.

People interested in the research are advised to contact the author for the final version of the publication, or visit the DOI to the publisher's website.

- The final author version and the galley proof are versions of the publication after peer review.

- The final published version features the final layout of the paper including the volume, issue and page numbers.

Link to publication

\footnotetext{
General rights rights.

- You may freely distribute the URL identifying the publication in the public portal. please follow below link for the End User Agreement:

www.umlib.nl/taverne-license

Take down policy

If you believe that this document breaches copyright please contact us at:

repository@maastrichtuniversity.nl

providing details and we will investigate your claim.
}

Copyright and moral rights for the publications made accessible in the public portal are retained by the authors and/or other copyright owners and it is a condition of accessing publications that users recognise and abide by the legal requirements associated with these

- Users may download and print one copy of any publication from the public portal for the purpose of private study or research.

- You may not further distribute the material or use it for any profit-making activity or commercial gain

If the publication is distributed under the terms of Article $25 \mathrm{fa}$ of the Dutch Copyright Act, indicated by the "Taverne" license above, 
Prof. mr.dr. Mieke Olaerts

Faculty of Law

The elephant in the Room: Over verbondenheid, macht en belangenafweging in het ondernemingsrecht 
Dear pro-rector, esteemed colleagues, dear family, friends and students

\section{The Elephant in the Room;}

\section{over verbondenheid, macht en belangenafweging in het ondernemingsrecht. ${ }^{1}$}

I do not know whether you have seen it as you entered this lecture hall today ... but as you may have gathered from today's invitation: there is an elephant in the room. The elephant being a metaphor in everyday language for an obvious problem or risk that no one wants to discuss.

In a way the title to this inaugural lecture is misleading as the elephant that I have in mind has been discussed at length and over many years. Nevertheless, despite countless attempts the ultimate solution to the problem has not yet been found. ${ }^{2}$

The elephant that takes centre stage today is a metaphor for the fact that even though companies nowadays often form part of a corporate group, ${ }^{3}$ many national company laws in Europe still take the single company as a point of departure. ${ }^{4}$ Moreover, in those cases where there is a national regulation of company groups in place, a systematic approach to the governance of these groups across national borders is still lacking.

Let me give an example to illustrate the underlying problem. Yesterday a new department store called Hudson's Bay opened its doors in Maastricht. The store is located in the former V\&D building. New shops are opened on several locations throughout the Netherlands as we speak, despite the fact that the Canadian parent company has suffered, according to the media, a netto loss of around $€ 286$ million Euro over the past six months. ${ }^{5}$ These large groups generally make use of a variety of subsidiaries set up in various countries. Each company is a separate legal entity with its own board of directors having its own duties and responsibilities on the basis of national law. These duties and responsibilities are often defined in company law as if the company was a self-standing independent legal person. At the same time however, one cannot

\footnotetext{
${ }^{1}$ Tekst van de inaugurele rede uitgesproken op 15 september 2017. Op onderdelen is deze schriftelijke weergave uitgebreider dan de spreektekst.

${ }^{2}$ During the 1980's plans were launched at the European level for a ninth company law directive on company groups largely based on the German model. However, this proposed directive was never adopted. See about this proposal C. Teichmann, 'Towards a European Framework for Cross-Border Group Management', ECL 13, no. 5 2016, p. 150. See also the Report of the High Level Group of Company Law Experts on A Modern Regulatory Framework for Company Law in Europe, November 2002, p. 94; European Commission Action Plan: European company law and corporate governance, COM (2012) 740 final and F. Chiappetta and U. Tombari, 'Perspectives on Group Governance and European Company Law', ECFR 2012, p. 262.

${ }^{3}$ Report of the Reflection Group on the Future of EU Company Law, April 2011, p. 59.

${ }^{4}$ Company groups give rise to the use of metaphors. Teichmann for example compares the absence of a clear approach to company groups with the tale of the emperor's clothes. C. Teichmann, 'Towards a European Framework for Cross-Border Group Management', ECL 13, no. 5, 2016, p. 150. See for a comparison of company groups with an octopus H. Fleischer, 'Europäisches Konzernrecht: Eine akteurzentrierte Annäherung', ZGR 2017, p. 16.

5 'Winkelopeningen drukken Hudson`s Bay dieper in het rood', Financieel Dagblad 6 september 2017.
} 
deny that these companies are interconnected and that the financial results of the parent company can have an influence on its subsidiaries. ${ }^{6}$

Just imagine that you are the director of a company that forms part of a large group such as Hudson`s bay or previously Imtech or V\&D. The parent company has persuaded you to sign a contract on the basis of which your company will be jointly and severally liable towards the bank for all loans provided to the group. After a few years the parent company decides that it would be best for the group as a whole to sell off parts of the business conducted by your company and use the proceeds to finance other activities within the group. You may think that this is perhaps not the greatest idea in the world with regard to the future prospects of your own company but if there is one thing your parents have taught you, it is not to question parental authority. Of course there may also be a correlation between your readiness for parental obedience and the fact that the parent company has the power to dismiss you as a director. A cause for concern however, is that at the same time company law requires you to act in the best interest of 'your own' company and that failing to do so may result in directors ' liability. Therefore, you are faced with a difficult dilemma. From the parent company's perspective survival of the group may depend on the obedience of directors at subsidiary level. The group as a whole may benefit from joint opportunities that may require a clear long-term group policy to be implemented at the various levels within the group.

Family life becomes even more complicated when parent and subsidiary operate under the law of different countries. Parent companies may not always be familiar with national rules at subsidiary level and it may therefore not always be clear to what extent they can push subsidiaries to live up to parental expectations. ${ }^{7}$ Parent companies coming from a more shareholder-oriented system may expect to be able to use their subsidiaries as an extension of their own company requiring the directors of those subsidiaries to mainly serve their interest as a shareholder. This may lead to a clash between corporate cultures especially when the subsidiary is incorporated in a more stakeholder-oriented system. ${ }^{8}$

These problems have been identified at the European level. In order to make life easier for parent companies and subsidiaries, the idea has emerged to come to a European wide recognition of the

\footnotetext{
${ }^{6}$ It should be mentioned that there are of course also countries that have in place a regulation specifically tailored towards groups of companies such as for example Germany or Portugal. In the Netherlands as in many other countries, despite the fact that some provisions of company law do take the group relation into account, the independent company still forms the point of departure. The group concept is to a certain extent recognized in several areas of the law as well as in case law but an all encompassing regulation of company groups is lacking. See in this respect F. Chiappetta and U. Tombari, 'Perspectives on Group Governance and European Company Law', ECFR 2012, p. 270.

${ }^{7}$ See in this respect the report of the informal Company Law Expert Group (ICLEG), Report on the recognition of the interest of the group, October 2016 available at https://ec.europa.eu/info/business-economy-euro/doing-businesseu/company-law-and-corporate-governance en\#preparatorywork

${ }^{8}$ See about the fact that recognition of the group interest may in general be easier in de country with a shareholdermodel ICLEG, Report on the recognition of the interest of the group, October 2016, p. 6.
} 
group interest. ${ }^{9}$ Such a recognition would facilitate the management of company groups throughout Europe as it would allow parent companies to manage the group in the joint interest while at the same time allowing directors of subsidiaries to give priority to that group interest without risking directors' liability. This would create so called 'safe harbours' for directors at both levels. ${ }^{10}$ With this European idea: the Elephant has once again been placed on the (European) agenda.

Key issues in the European debate are the need to recognize the group interest in order to enable group management across borders and retaining flexibility ${ }^{11}$ while at the same time creating safe harbours for directors at the various levels within the group.

What I want to do today is discuss the potential consequences of the European idea of the recognition of the group interest from a Dutch perspective focusing on these key issues. Today's lecture consist of four parts: I will first of all go into the background idea and trend which underlies this European development and see if and how it corresponds to or deviates from the development at the (Dutch) national level. In the second part of this lecture I will discuss how the European idea of the recognition of the group interest fits into the Dutch system. In the third part I will sketch potential roads ahead taking into account European and national developments. At the end of this inaugural lecture I will say a few words on how this fits into my future research and teaching ambitions.

\footnotetext{
${ }^{9}$ As proposed in the report of the Reflection Group on the Future of EU Company Law, April 2011, p. 59 and the European Commission Action Plan: European company law and corporate governance, COM (2012) 740 final. ${ }^{10}$ Report of the Reflection Group on the Future of EU Company Law, April 2011, p. 60. Following the European Commissions support of the idea to come to a recognition of a group interest, several working groups (either informally or instigated by the European Commission) made proposals on how the recognition of the group interest could be implemented in practice. A final approach at the European level is however still lacking. See with regard to these proposals for example Forum Europaeum on Company Groups: 'Proposal to Facilitate the Management of Cross-Border company Groups in Europe', ECFR 2015, p. 299-306; The report of the informal company law expert group instigated by the European Commission: ICLEG, Report on the Recognition of the Group Interest, October 2016. See with regard to the recognition of the group interest also chapter 15 of the European Model Company Act (EMCA). The EMCA cannot be considered as one of the proposal with regard to how the recognition of the group interest could be implemented at the European level. The EMCA is broader, it is a model act on company law that can be used as a template by private parties as well as Member Sates when considering to make changes to their national law. The group interest is one of the topics that is taken into account in this model act. See for a discussion of the chapter of the EMCA on company groups: P.H. Conac, 'The Chapter on Groups of Companies of the European Model Company Act', ECFR 2016, p. 301-321. The EMCA can be found on the EMCA website: http://law.au.dk/forskning/projekter/europeanmodelcompanyactemca/. There are also a number of national proposals for further regulation of group relations. See for example the proposals by the Luxembourg Institute of Directors and the French Club des Juristes. About these initiatives: C. Teichmann, 'Towards a European Framework for CrossBorder Group Management', ECL 13, no. 5, 2016, p. 150-157. See also the proposals by the European Company Law Experts (ECLE), A proposal for reforming group law in the European Union-Comparative Observations on the way forward, October 2016 available at https://europeancompanylawexperts.wordpress.com.

${ }^{11}$ See for example report of the Reflection Group on the Future of EU Company Law, April 2011, p. 11, Chapter 15 EMCA, under general comments p. 466. Conac who is of the opinion that the right to give instructions should not be dependent on a previously made choice, declaration or contract between the parent company and its subsidiaries P.H. Conac, 'Director's Duties in Groups of Companies- Legalizing the Interest of the Group at the European Level', ECFR 2013, p. 216.
} 
As you probably have noticed by now: I started this lecture in English. The reason for this is that working in an international environment and doing research and teaching in a multi-lingual setting at Maastricht University has by now become part of our and also my DNA. As the main part of my inaugural lecture is related to Dutch law, I will switch to the Dutch language. I will return to English at the end of this lecture when I set out my future teaching ambitions.

\section{Achtergrond en trend op nationaal en EU-niveau}

Beste toehoorders, zoals gezegd, ga ik eerst kort in op de achtergrond van de Europese en nationale ontwikkelingen.

Door de jaren heen is op Europees niveau in het debat omtrent de regulering van het concern een trend waarneembaar waarbij minder dan voorheen de nadruk wordt gelegd op de noodzaak van bescherming. Oorspronkelijk stonden de Europese ideeën over harmonisatie van concernverhoudingen in de sleutel van het opzetten van een robuust systeem aan concernregelgeving om vooral minderheidsaandeelhouders en crediteuren zo goed mogelijk te beschermen tegen de mogelijke concerngevaren. Denk daarbij bijvoorbeeld aan het risico dat een moedervennootschap haar macht gebruikt om financiële middelen aan haar dochter te onttrekken en in te zetten voor haar eigen gewin terwijl zij de schuldeisers van de dochter met lege handen achterlaat. Deze ontwikkeling heeft plaats gemaakt of wordt thans geflankeerd door, wat in de literatuur wordt omschreven als, een meer 'enabling' aanpak van concernverhoudingen. Dat laatste zou ik vrij willen vertalen naar: het mogelijk maken van of nog korter gezegd het faciliteren van concernleiding. Daarmee lijkt een eerder negatieve, op het voorkomen van risico`s gerichte, aanpak te worden ingeruild voor een meer positieve aanpak die gericht is op het realiseren van de voordelen die aan concerns verbonden zijn.

Pogingen die in het verleden gedaan zijn om het concernrecht binnen Europa te harmoniseren, waarbij juist die beschermende aanpak voorop stond, zijn zoals gezegd al eind jaren 70 en begin jaren 80 gestrand met het ter ziele gaan van het voorstel voor een negende richtlijn. ${ }^{12}$ In plaats daarvan is men nu op zoek naar een systeem waarin het concern als één geheel kan worden geleid... Bij een dergelijke faciliterende aanpak past meer aandacht voor de wijze waarop aan de interne verhoudingen gestalte kan worden gegeven waarbij recht wordt gedaan aan de bijzondere karakteristieken van het concern. Europa is met andere woorden op zoek naar een vennootschapsrechtelijk instrumentarium dat concernmanagement, ook over de grenzen heen, mogelijk maakt. Het op de voorgrond treden van het concernbelang is interessant omdat het aanleiding geeft tot het nader concretiseren van de gedachten omtrent concern governance waarbij een stap verder wordt gegaan dan de bestaande, veelal casuïstische en op de jurisprudentie gebaseerde, aanpak. In plaats daarvan moeten bestuurders op dochter en centraal niveau duidelijkere handvaten worden geboden om de aan het concern ten grondslag liggende

\footnotetext{
${ }^{12}$ Zoals reeds aangegeven (zie voetnoot 2 hiervoor) was er jaren geleden een voorstel voor een negende richtlijn inzake concernverhoudingen naar Duits model. Zie hierover F. Chiappetta and U. Tombari, Perspectives on Group Governance and European Company Law, ECFR 2012, p. 270.
} 
onderneming op verantwoorde wijze te kunnen leiden. ${ }^{13}$ De Europese discussie wordt, zoals hiervoor reeds aangegeven, gekenmerkt door: i. een verandering van een meer beschermende aanpak naar een meer faciliterende aanpak enerzijds en ii. de wens tot het behouden van een flexibiliteit in de concernstructuur door het vermijden van té prescriptieve regelgeving ten aanzien van de concernstructuur.

Vergelijken we nu het Nederlands concernrechtelijk landschap met de Europese ontwikkelingen ten aanzien van het eerste punt, dan valt op dat hier te lande inmiddels, net als in de meeste Europese lidstaten, sporen van zowel de beschermende als de faciliterende aanpak terug te vinden zijn waarbij in toenemende mate ook aandacht is voor de wijze waarop het concern wordt geleid. $^{14}$

Alvorens dit nader uiteen te zetten aan de hand van een aantal voorbeelden, ga ik eerst nog kort in op de ondertitel van deze oratie die verbondenheid, macht en belangenafweging centraal stelt. Het is de driehoeksverhouding tussen verbondenheid, macht en belangenafweging die een belangrijke karakteristiek vormt van de concerndynamiek en de traditionele concernregulering. De verbondenheid tussen concernvennootschappen komt tot stand door enige vorm van invloed of zeggenschap van de ene rechtspersoon op of over de andere. Verbondenheid kan aanleiding geven tot machtsuitoefening. De mate waarin binnen groepsverhoudingen macht wordt uitgeoefend, kan sterk verschillen. Het is vervolgens, in de traditionele benadering zoals die bijvoorbeeld voortvloeit uit de Nederlandse doorbraakjurisprudentie, de machtsuitoefening die door de concernleiding die aanleiding geeft om in verdergaande mate met een pluraliteit aan belangen rekening te houden. Zowel op nationaal als op Europees niveau is het vooralsnog zoeken naar de juiste balans tussen het erkennen van het concernbelang enerzijds en de consequenties daarvan voor de concernleiding en het dochterbestuur anderzijds. ${ }^{15}$ De vraag die

\footnotetext{
${ }^{13}$ Zie eveneens Teichmann, 'Towards a European Framework for Cross-Border Group Management', ECL 13, no. 5 2016, p. 150-157.

${ }^{14}$ Overigens is het zeker niet zo dat, zoals gebruikelijk bij de olifant in de kamer, deze olifant in Nederland wordt doodgezwegen. De ontwikkelingen ten aanzien van het concernrechtelijk denken hebben in ons land sedert de jaren zeventig een vlucht genomen. Zie voor een beknopt overzicht ten aanzien van de ontwikkelingen in de literatuur van de jaren 70 tot de jaren 90 W.J. Slagter, 'Interne en externe concernverhoudingen', in: J.M.M. Maeijer e.a., De Bankier als Jurist tegen wil en dank, Kluwer: Deventer 1991, p. 191. Ook daarna is over concernverhoudingen, de concernleidingsplicht en de autonomie van het bestuur op dochterniveau veel geschreven. Ik kan hier onmogelijk volledig zijn maar noem slechts als voorbeelden de verschillende bijdragen in het boek L. Timmerman e.a. Concernverhoudingen, Deventer: Kluwer 2002; A.F. Verdam e.a., Autonomie van het bestuur en haar grenzen voor en na de Cancun-uitspraak, Deventer: Kluwer 2015. Zie over het verschil tussen juridische en economische werkelijkheid onder meer J.B. Huizink, Een adequaat vehikel? (oratie VU) Deventer: Kluwer, 2001; S.M. Bartman, Voorbij NV en BV; Over Corporate Governance en het tekort van ons vennootschapsrecht, (Oratie Leiden), 2004; A.F.M. Dorresteijn, Substance over form in het ondernemingsrecht? (oratie Utrecht), Kluwer: Deventer 2004. ${ }^{15}$ In de verschillende voorstellen ten aanzien van de wijze waarop aan de erkenning van het concernbelang gestalte kan worden gegeven lopen de ideeën hierover uit elkaar. Volgens sommige voorstellen zou het geven van instructies door de concernleiding gepaard moeten gaan met het instellen van een zogenaamde wrongful trading rule op basis waarvan de concernleiding dient in te grijpen wanneer de dochtervennootschap in financieel zwaar weer terecht dreigt te komen. Zie in dit verband bijvoorbeeld art. 15.17 van de EMCA. Het Forum Europaeum on company groups maakt daarentegen een onderscheid tussen 'service companies en ordinary companies' waarvoor een ander regime zou moeten gelden, Forum Europaeum on Company Groups, 'Proposal to Facilitate the Management of
} 
daarbij opkomt is hoe en op welk niveau de belangenafweging dient plaats te vinden. ${ }^{16}$ Nadat de gedachte om te komen tot de erkenning van het concernbelang door de Europese Commissie werd omarmd, is een aantal informele werkgroepen in de pen gekropen om aan deze gedachte vorm en inhoud te geven. ${ }^{17}$ Een definitieve aanpak op Europees niveau, waarbij richtlijnen worden gegeven over hoe met deze driehoeksverhouding dient te worden omgegaan, ontbreekt echter nog.

Uitgaande van het Nederlandse vennootschapsrecht, ontstaat verbondenheid al vrij snel. Zo ontstaat de verplichting om te consolideren wanneer een rechtspersoon overheersende zeggenschap over een andere rechtspersoon kan uitoefenen. Het uitoefenen van effectieve zeggenschap, of met andere woorden, het daadwerkelijk gebruikmaken van die macht is daarbij niet relevant. ${ }^{18}$

De onderlinge verbondenheid tussen vennootschappen geeft aanleiding tot een aantal verplichtingen maar ook tot een aantal vrijstellingen. Daarmee zijn in het Nederlandse recht inmiddels, evenals in de meeste andere landen, sporen van zowel de beschermende aanpak als de faciliterende aanpak terug te vinden. ${ }^{19}$

De beschermingsgedachte komt op meerdere plaatsen in de wet voor: denk bijvoorbeeld aan de bescherming van werknemers door het instellen van een gemeenschappelijke ondernemingsraad bij in een groep verbonden ondernemers. ${ }^{20}$

Facilitering van concernverhoudingen is óók terug te vinden in de wet: zo zijn er bijvoorbeeld bepalingen die voorzien in het vrijstellen of het vereenvoudigen van wettelijke regelingen specifiek voor concernverhoudingen. Ik denk daarbij bijvoorbeeld aan de 403-verklaring die het mogelijk maakt om voor (ondergeschikte) groepsmaatschappijen af te wijken van het strakke keurslijf van de inrichting en publicatie van de jaarrekening. Een andere belangrijke facilitering

Cross-Border Company Groups in Europe', ECFR 2015, p. 303 e.v. Zie voor uitgebreid commentaar op deze laatste voorstellen het themanummer P. Hommelhoff, M. Lutter en C. Teichmann, Corporate Governance im Konzern, ZGR 2017/20.

${ }^{16}$ Een erkenning van het concernbelang vergt immers een zekere tegensprestatie van de concernleiding of in ieder geval een eerlijke verdeling van voor-en nadelen over de groep. Zie Report of the High Level Group of Company Law Experts on A Modern Regulatory Framework for Company Law in Europe, November 2002, p. 97.

${ }^{17} \mathrm{Zie}$ onder meer de initiatieven genoemd in voetnoot 10 hiervoor.

${ }^{18}$ Zie hierover A.F.M. Dorresteijn, Groene Serie Rechtspersonen, art. 2:24a BW, aant. 6.

${ }^{19}$ Zoals gezegd gaat het Nederlandse vennootschapsrecht uit van de enkelvoudige vennootschappen. Ongeacht de verbondenheid tussen concernvennootschappen, wordt voor wat betreft de interne governance zoals onder meer de bevoegdheidsverdeling tussen de verschillende organen uitgegaan van de enkelvoudige vennootschap. Wel wordt op meerdere plaatsen, zowel in Boek $2 \mathrm{BW}$ als daarbuiten, rekening gehouden met het feit dat vennootschappen onderling met elkaar verbonden kunnen zijn. Zie hierover S.M. Bartman. A.F.M. Dorresteijn en M. Olaerts, Van het Concern, Deventer: Kluwer 2016, hoofdstuk II.

${ }^{20}$ Art. 3 lid 2 WOR. Zie hierover S.M. Bartman, A.F.M. Dorresteijn, M. Olaerts, Van het concern, Deventer: Kluwer 2016, p. 38. 
van de concernleiding is te vinden in de statutaire instructiebevoegdheid die bij de flexibilisering van het BV-recht is geïntroduceerd. ${ }^{21}$

Beide gedachten - bescherming en facilitering - zijn verder tot wasdom gekomen in de jurisprudentie. Zo wordt concernmanagement onder meer mogelijk gemaakt doordat men vrij flexibel omgaat met concernfinanciering. In deze lijn van rechtspraak wordt bijvoorbeeld aangenomen dat als concernvennootschappen over en weer zekerheden afgeven in ruil voor het verkrijgen van een gezamenlijke financiering van de bank, dit niet snel buiten het doel van de vennootschap zal vallen en dus toegestaan is. ${ }^{22}$

De beschermingsgedachte heeft vooral bij de doorbraak-jurisprudentie vooropgestaan. Op basis van die jurisprudentie kan een moedervennootschap onder omstandigheden aansprakelijk worden gesteld door de schuldeisers van haar dochter wanneer zij zich intensief heeft bemoeid met de gang van zaken op dochterniveau en de crediteuren hierdoor zijn gedupeerd. In die doorbraakjurisprudentie heeft door de jaren heen een verschuiving plaatsgevonden. Waar eerst de nadruk lag op aansprakelijkheid van de moedervennootschap omdat zij misbruik maakte van haar positie door bijvoorbeeld vermogen over te hevelen en zichzelf zo te bevoordelen, is via het ontwikkelen van zorgplichten meer nadruk komen te liggen op het op verantwoorde wijze gestalte geven aan de concernrelatie. Deze ontwikkeling naar meer organisatierecht, die ook in de literatuur is gesignaleerd, ${ }^{23}$ laat niet zozeer zien dat de concernleiding wordt gefaciliteerd maar wel dat concernleiding als een gegeven wordt aanvaard en dat er een in de jurisprudentie ontwikkeld systeem is van zorgplichten voor die concernleiding. Het bestaan van die zorgplichten is dan weer afhankelijk van de wijze waarop en de mate waarin de moedervennootschap haar macht uitoefent. De verbondenheid maakt met andere woorden een machtsuitoefening mogelijk die kan leiden tot aansprakelijkheid wanneer de betrokken belangen onvoldoende zijn afgewogen. In die gevallen waarin doorbraak van aansprakelijkheid wordt toegewezen, is doorgaans van een vergaande vorm van machtsuitoefening sprake en nemen ook de verantwoordelijkheden van de concernleiding verhoudingsgewijs toe. Voor het creëren van een zorgplicht als basis voor een eventuele doorbraak van aansprakelijkheid is in beginsel het enkel hebben van meerderheidsmacht of het voeren van de concernleiding onvoldoende. Bijkomende omstandigheden zijn vereist die ervoor zorgen dat op de moedervennootschap een zorgplicht komt te rusten jegens de crediteuren van de dochter. Het gaat daarbij om een achteraf bewezen 'hechte concernband' waarbij de moedervennootschap zich intensief heeft bemoeid met het beleid op dochterniveau. De intensieve bemoeienis van de moeder op dochterniveau en de nauwe verwevenheid tussen de concernvennootschappen creëert een zorgplicht van de

\footnotetext{
21 Art. 2:239 lid 4 BW.

${ }^{22}$ Zie hierover met literatuurverwijzing S.M. Bartman, A.F.M. Dorresteijn en M. Olaerts, Van het concern, Deventer: Kluwer 2016, VII.4.3, p. 227 e.v. Zie recentelijk HR 3 maart 2017, JOR 2017/84 m.nt. A.F.J.A. Leijten.

${ }^{23}$ Zie hierover en voor een verwijzing naar de relevante doorbraakjurisprudentie S.M. Bartman, A.F.M. Dorresteijn en M. Olaerts, Van het concern, Deventer: Kluwer 2016, hoofdstuk VIII, p. 256 e.v.
} 
concernleiding ten aanzien van de crediteuren van de dochter. ${ }^{24}$ Het intreden van de aansprakelijkheid van de moedervennootschap is afhankelijk van de omstandigheden van het geval waarbij die omstandigheden kunnen worden ingedeeld in een aantal categorieën van verweten gedragingen zoals het wekken van de schijn van kredietwaardigheid, het doen van vermogensonttrekkingen, het voortzetten van verliesgevende dochtervennootschappen etc. of een combinatie van die factoren. ${ }^{25}$ In de praktijk zorgt de casuïstische wijze waarop deze zorgplichten tot ontwikkeling zijn gekomen echter voor de nodige onduidelijkheid ten aanzien van hoe in concrete gevallen door zowel bestuurders op dochter als op concernleidingsniveau dient te worden gehandeld.

Niet alleen in de doorbraak-jurisprudentie maar ook in het enquêterecht is aandacht voor de manier waarop concerns worden geleid en de interne samenhang binnen het concern. Sinds de Ogem-uitspraak van de Hoge Raad in de jaren 90 van de vorige eeuw wordt een zogenaamde concernleidingsplicht aangenomen. Helaas is nog niet duidelijk uitgewerkt wat die concernleidingsplicht precies inhoudt. ${ }^{26}$ De verbondenheid tussen vennootschappen en het hebben van 'ingrijpmacht' kan in ieder geval aanleiding geven tot het moeten voeren van een zekere concernleiding waarbij de macht ook moet worden aangewend op lager gelegen niveaus binnen het concern. ${ }^{27}$ Volgens de Hoge Raad was de Ondernemingskamer er in de Ogem-zaak terecht vanuit gegaan dat de bestuurstaak op holding niveau zich mede uitstrekt tot de tot het concern behorende ondernemingen. De vrijheid om in de interne inrichting van het concern de teugels te laten vieren, is sinds de Ogem-enquête derhalve in zoverre beperkt dat het hebben van macht ertoe kan leiden dat die ook aangewend moet worden op lager gelegen niveaus binnen het concern. $^{28}$

Een voorbeeld van een zaak waarin ruim aandacht is besteed aan de wijze waarop het concern intern werd geleid, is de inmiddels al weer gecasseerde Meavita beschikking van de Ondernemingskamer uit 2015. ${ }^{29}$ In deze zaak werd na een fusie tussen zorginstellingen gekozen voor een zogenaamde 'decentrale sturingsfilosofie' waarbij slechts sprake was van een 'lichte' holding. ${ }^{30}$ De Ondernemingskamer was van oordeel dat de centrale sturing tekortschoot en dat dat bijdroeg aan het oordeel wanbeleid. De noodzaak voor een meer centrale sturing werd onder meer gemotiveerd door te kijken naar de onderneming en de daaraan ten grondslag liggende

\footnotetext{
${ }^{24}$ S.M. Bartman, A.F.M. Dorresteijn en M. Olaerts, Van het Concern, Deventer: Kluwer 2016, hoofdstuk VIII.4, p. 262 e.v. Zie hierover onder meer A.J.M. Klein Wassink, 'Gedachten over de invulling van moederlijke zorgplichten in doorbraaksituaties', Ondernemingsrecht 2016/79.

${ }^{25}$ Zie hierover M. Olaerts, 'Vennootschappelijke beleidsbepaling in geval van financiële moeilijkheden; de positie van bestuurders en aandeelhouders' (diss.), Antwerpen-Oxford: Intersentia 2007, p. 204 e.v.; zie voorts onder meer B.F. Assink/W.J. Slagter, Compendium Ondernemingsrecht (Deel II), Deeventer: Kluwer 2013, § 115.3, p. 2262 e.v.

${ }^{26}$ Zie S.M. Bartman, 'Hoge Raad weet zich niet goed raad met het concern', Ondernemingsrecht 2016/77.

${ }^{27}$ HR 10 januari 1990, NJ 1990/466 m.nt. J.M.M. Maeijer.

${ }^{28}$ HR 10 januari 1990, NJ 1990/466 m.nt. J.M.M. Maeijer.

${ }^{29}$ OK 2 november 2015, JOR 2016/61, m.nt. PvS (Meavita). De beschikking werd later door de Hoge Raad gecasseerd omdat deze niet was gewezen door het aantal in de wet bepaalde rechters zie Hoge Raad 18 november 2016, ECLI:NL:HR:2016:2607.

${ }^{30}$ Hof Amsterdam (OK) 2 november 2015, JOR 2016/61 m.nt. P. van Schilfgaarde.
} 
doelstellingen. Uit het onderzoeksverslag bleek bijvoorbeeld dat er een aantal duidelijke concernbrede ambities waren die zonder centrale sturing niet konden worden gerealiseerd. De verantwoordelijkheid tot het voeren van een gedegen beleid wordt daarmee van concernrechtelijke contouren voorzien waarbij de verantwoordelijkheid bij de concernleiding wordt gelegd. ${ }^{31}$ De nadruk bij de ontwikkeling van de besproken concernleidingsplicht en de zorgplicht op basis van de doorbraakjurisprudentie, heeft steeds gelegen op de verplichtingen van de concernleiding waarbij de gedachte voorop heeft gestaan dat voor het uitoefenen van macht een zekere prijs moet worden betaald teneinde de belangen van derden te beschermen.

Intussen zien we dat die concernleidingsplicht zich via de corporate governance ontwikkelingen verder uitbreidt. ${ }^{32}$ Opvallend is dat daarin wellicht niet zozeer het beschermen van derden tegen de risico's van misbruik voorop staat maar een andersoortige risico benadering; namelijk de gedachte dat risico`s op lager gelegen niveaus het gehele concern kunnen infecteren. Dit heeft met name geleid tot een verdere verzwaring van de concernlasten voor de top, maar niet zozeer tot het faciliteren van de concernleiding. De corporate governance code schrijft bijvoorbeeld voor dat de vennootschap moet beschikken over adequate risicobeheersings- en controlesystemen. ${ }^{33}$ Algemeen wordt aangenomen dat die systemen zich niet beperken tot de eigen vennootschap maar dat de verplichtingen zich uitstrekken tot het hele concern. De moedervennootschap moet inzicht hebben in en controle hebben over de mogelijke risico`s op dochterniveau omdat die ook van invloed kunnen zijn op de eigen bedrijfsvoering. Deze verplichtingen worden gekoppeld aan de bestuurstaak van de concernleiding. Ook bij nietbeursvennootschappen wordt er inmiddels vanuit gegaan dat de bestuurs- en toezichthoudende taak van de concernleiding zich mede uitstrekken over de onderliggende concernvennootschappen. ${ }^{34}$

Als tweede kernpunt in de Europese discussie noemde ik flexibiliteit. In het Nederlandse concernrecht staat voor wat betreft het vormgeven aan de interne verhoudingen maar ook voor wat betreft de wijze van concernregulering flexibiliteit voorop. Het concern wordt niet als zodanig volledig door Boek $2 \mathrm{BW}$ gereguleerd. Op plaatsen wordt met het concernfenomeen

\footnotetext{
${ }^{31}$ Zie over deze zaak onder meer C. de Groot, 'Wanbeleid bij Meavita?', $M v O$ 2016/2, p. 31-38 en M.J.G.C. Raaijmakers, 'Meavita: van 'wanbeleid rechtspersoon' naar aansprakelijkheid bestuurders/commissarissen?!', $A A$ 2016, p. 191-200.

32 Zie hierover S.M. Bartman, Voorbij NV en BV; Over Corporate Governance en het tekort van ons vennootschapsrecht, (Oratie Leiden), 2004.

${ }^{33}$ Principe 1.2 van de Nederlandse Corporate Governance Code 2016. Over de effectiviteit van die systemen dient het bestuur een zogenaamde 'in controle' verklaring af te geven. Zie Best Practice 1.2.2 van de Nederlandse Corporate Govenance Code 2016. Ten aanzien van financiële instelling wordt het concern als zodanig eveneens erkend vanuit de gedachte van risicomanagement. Zie in dit verband bijvoorbeeld de bepalingen van de CRD IV richtlijn: Richtlijn 2013/36/EU betreffende toegang tot het bedrijf van kredietinstellingen en het prudentieel toezicht op kredietinstellingen en beleggingsondernemingen, art. 74 e.v. op basis waarvan instellingen moeten beschikken over een solide governance regeling en organisatiestructuur met systemen voor beheer, detectie, bewaking en rapportage van risico`s. Zie hierover ICLEG, Report on the Recognition of the Group Interest, oktober 2016, p. 15 e.v.

${ }^{34}$ HR 10 januari 1990 (r.o. 9.2), NJ 1990/466 (Ogem). Asser/Maeijer, Van Solinge \& Nieuwe Weme 2-II* 2009/827.
} 
rekening gehouden, met name in die gevallen waarin de concernverhouding noopt tot het creëren van extra waarborgen ter bescherming van de belangen van stakeholders. De onderlinge verbondenheid tussen concernvennootschappen kan juridische consequenties hebben zoals de concernleidingsplicht die ik net noemde. Machtsuitoefening door de concernleiding kan zich, afhankelijk van de hechtheid van het concernverband, in verschillende gradaties voordoen waarbij de concernleiding veel vrijheid toekomt voor wat betreft de wijze waarop het concern wordt geleid. ${ }^{35}$ Wanneer de machtsuitoefening intensiever wordt, zal de concernleiding een verdergaande verantwoordelijkheid moeten accepteren voor wat betreft de noodzakelijke behartiging van de betrokken belangen op dochterniveau. Waar het gaat om concernleiding, is met andere woorden sprake van een glijdende schaal van weinig naar meer betrokkenheid waarbij de verplichting om met een veelheid aan belangen, die op verschillende niveaus spelen, rekening te houden verhoudingsgewijs toeneemt.

Als ik nu een tussenbalans opmaak, dan kunnen we vaststellen dat in het Nederlandse concernrechtelijke systeem zowel bescherming tegen misbruik als facilitering naar vorenkomt. Flexibiliteit wordt geboden doordat de concernleiding vrij is in de wijze waarop het concern wordt ingericht. Boek $2 \mathrm{BW}$ bevat daarover weinig voorschriften. Wel is het zoeken naar de juiste balans tussen machtsuitoefening en de daarmee gepaard gaande belangenafweging. We weten dat een te vergaande machtsuitoefening aanleiding kan geven tot aansprakelijkheid wanneer onvoldoende rekening wordt gehouden met belanghebbenden op de verschillende niveaus binnen het concern. In toenemende mate lijkt er aandacht in de jurisprudentie voor de wijze waarop aan de concernleiding gestalte is gegeven. De contouren daarvan zijn echter niet altijd scherp te trekken. In de traditionele doorbraak-jurisprudentie is het machtsuitoefening die aanleiding geeft tot aansprakelijkheid bij een gebrek aan belangenafweging. Echter, zoals hierna nog zal blijken, zal het kantelpunt zowel voor de concernleiding als voor het bestuur op dochterniveau in de praktijk niet altijd eenvoudig vast te stellen zijn. Daarnaast zien we in de jurisprudentie incidenteel aandacht voor de wijze waarop het concern wordt geleid, hetgeen echter nog niet heeft geleid tot een duidelijk kader voor 'concern governance'. Een vraag die daarbij speelt is of verbondenheid in de toekomst ook zonder specifieke machtsuitoefening aanleiding kan geven tot een verplichting van de moedervennootschap om zorg te dragen voor een belangenafweging op dochterniveau en wat de rol daarin is van het bestuur van die dochter.

2. De erkenning van het concernbelang en het Nederlandse systeem

Ik kom daarmee tot het tweede deel van mijn lezing namelijk de beantwoording van de vraag hoe de erkenning van het concernbelang past binnen het Nederlandse systeem.

\footnotetext{
${ }^{35}$ Huizink schreef in dit verband eerder dat doordat de eis van intensieve bemoeienis in de doorbraak jurisprudentie wordt gesteld, het lijkt alsof een moedervennootschap zich aan haar verantwoordelijkheid kan onttrekken door zich niet intensief met het beleid en de gang van zaken van die dochter te bemoeien. Volgens hem kan dit niet de bedoeling zijn en is er sprake van 'consolidatie for better and for worse'. Zie J.B. Huizink. 'Van lusten en lasten;, $T v I$ 2002, p. 309. Zie verder eveneens J.B. Huizink, 'Zorgplichten in het concern', $O \& F 2010$ (18), p. 17. Zie voorts over de keuzevrijheid in concernstructuren onder meer M.J.G.C. Raaijmakers, 'Bestuursautonomie in een (gezamenlijke) dochter-B.V.: een novum in concernverhoudingen?', TvOB 2015/1, p. 2-12.
} 
De erkenning van het concernbelang zal, zoals collega Bartman in zijn artikel in Ondernemingsrecht schreef, geen schok teweegbrengen in het Nederlandse systeem. ${ }^{36}$ Nederland erkent, evenals een groot aantal andere Europese landen, al tot op zekere hoogte het concernbelang. Maar daarmee is meteen ook een knelpunt aangegeven: 'tot op zekere hoogte'. Die hoogte is niet altijd duidelijk aan te geven en die onduidelijkheid is het gevolg van het feit dat de erkenning van het concernbelang in de jurisprudentie gestalte heeft gekregen en dus sterk casuïstisch van aard is. Bartman gaf in datzelfde artikel ook aan dat de erkenning van het concern als geheel door de Hoge Raad niet altijd op eenduidige wijze gestalte krijgt. Ik ga die bespreking hier niet nog eens overdoen maar geef alvast mee dat die erkenning vaak context afhankelijk is. Zo wordt het concern als geheel eenvoudiger erkend in het kader van de medezeggenschap van werknemers of in het enquêterecht dan bij de meer vermogensrechtelijke thema`s zoals bijvoorbeeld ten aanzien van de draagplichtproblematiek. ${ }^{37}$

Typerend voor de Nederlandse systematiek is dat de erkenning van het concernbelang steeds dient te verlopen via het vennootschappelijk belang. Aan de basis van het Nederlandse vennootschapsrecht ligt het stakeholdermodel dat stevig verankerd is in de gedachte van het vennootschappelijk belang. In de wetgeving en de rechtspraak wordt strak de hand gehouden aan een veelzijdige belangenafweging door het bestuur en de raad van commissarissen waarbij het eigen vennootschappelijk belang centraal staat. Dat vennootschappelijk belang bestaat, sinds de Cancun uitspraak van de Hoge Raad, bij een vennootschap waar een onderneming aan verbonden is uit het bevorderen van het bestendig succes van die onderneming. ${ }^{38}$ De oorspronkelijke gedachte dat de vennootschap gezien moet worden als een contract tussen aandeelhouders is verlaten en heeft plaats gemaakt voor de institutionele visie waarin de vennootschap wordt gezien als een op zichzelf staand instituut met een eigen vennootschappelijk belang. ${ }^{39}$ Ook bij de introductie van de instructiebevoegdheid in het BV-recht, is dat vennootschappelijk belang centraal blijven staan. Het bestuur moet aanwijzingen opvolgen tenzij het belang van de vennootschap en de daarmee verbonden onderneming zich daartegen verzet. ${ }^{40}$ Aangenomen wordt wel dat het vennootschappelijk belang van een dochter door het concernbelang wordt ingekleurd. ${ }^{41}$ In de Corus-zaak expliciteerde de Ondernemingskamer bijvoorbeeld de

\footnotetext{
${ }^{36}$ S.M. Bartman, 'Hoge Raad weet zich niet goed raad met het concern', Ondernemingsrecht 2016/77.

${ }^{37}$ S.M. Bartman, 'Hoge Raad weet zich niet goed raad met het concern', Ondernemingsrecht 2016/77.

${ }^{38}$ HR 4 april 2014, NJ 2014/286, m.nt. PvS, JOR 2014/290, m.nt. De Haan (Cancun).

${ }^{39}$ Zie onder meer J.M. De Jongh, 'Redelijkheid en billijkheid en het evenredigheidsbeginsel, in het bijzonder in de verhouding van aandeelhouders tot het bestuur', Ondernemingsrecht 2011/124. Zie over deze ontwikkeling F.G.K. Overkleeft, De positie van aandeelhouders in beursvennootschappen (Instituut voor Ondernemingsrecht nr.

103),Deventer: Kluwer 2017, hoofdstuk 2.

${ }^{40}$ Art. 2:239 lid 4 BW.

${ }^{41} \mathrm{Zie}$ over de verhouding tussen het concernbelang en het vennootschappelijk belang onder meer G.J.H. van der Sangen, 'Concernleiding en aansprakelijkheid: het delicate evenwicht tussen unitaire leiding en juridische zelfstandigheid', $T v O B$ 2009, afl. 6, p. 147, G.J.H. van der Sangen, 'De curator in het vennootschapsrecht: onderstromen en schuivende panelen', $T v O B$ 2012/2, p. 61-69. R.G.M. Dahmen, 'De aanwijzingsbevoegdheid van het gewijzigde artikel 2:239-4 BW: toepassing, toetsing, afdwingbaarheid en aspecten van aansprakelijkheid in concernperspectief', TvOB 2014/2, p. 61-71; D. Mokhberolsafa, 'Instructiebevoegdheid en de aansprakelijkheid van de moedervennootschap als medebeleidsbepaler van haar dochter-bv op grond van art. 2:248 lid 7 BW: een kwestie
} 
wisselwerking tussen het concern- en het vennootschappelijk belang: een dochter mag niet zonder meer een beleid voeren waarbij geen rekening wordt gehouden met de concernstrategie... en zal onder omstandigheden moeten aanvaarden dat haar belang wordt achtergesteld bij het concernbelang. ${ }^{42}$ De concernleiding mag, van de andere kant, de belangen van de dochtervennootschappen niet zonder meer achterstellen bij dat concernbelang. De verbondenheid zorgt er met andere woorden voor dat bestuurders op de verschillende concernniveaus zich redelijk moeten opstellen met een openvizier en onder afweging van zowel het concern- als het vennootschappelijk belang. ${ }^{43}$ Daarmee dwingt de lijn in de jurisprudentie bestuurders tot een duidelijk afwegingsproces dat voldoende gedocumenteerd moet zijn.

Hoewel hiermee de invloed en de betekenis van het concernbelang wordt erkend, biedt deze benadering bestuurders (zowel op moeder als op dochterniveau) weinig houvast wanneer zij zich gesteld zien voor concrete beslissingen. Het vennootschappelijk- en het concernbelang wijzen lang niet altijd dezelfde weg, dat zal met name het geval zijn wanneer het concern in financiële moeilijkheden verkeert. De vraag waar de grens ligt tussen het concern- en het vennootschappelijk belang is niet steeds eenvoudig te beantwoorden. Daarbij helpt niet dat de Hoge Raad in het kader van de Juno-properties zaak, ${ }^{44}$ kort gezegd, beslist heeft dat voor iedere tot het concern behorende vennootschap afzonderlijk moet worden beoordeeld of het bestuur van de vennootschap haar taak onbehoorlijk heeft vervuld. Bij het beantwoorden van de vraag of het bestuur behoorlijk heeft gehandeld, mag het feit dat bepaalde verrichtingen zijn gedaan in het kader van het concernbelang wel meewegen maar dat concernbelang mag niet bij voorbaat doorslaggevend zijn. Om bestuurdersaansprakelijkheid te voorkomen, zal het bestuur op dochterniveau er dus voor moeten waken dat die vennootschap aan haar verplichtingen jegens de betrokken stakeholders kan blijven voldoen en daarbij een eigen afweging moeten maken. ${ }^{45}$ Tot zoverre is de Nederlandse systematiek duidelijk: het concernbelang wordt erkend mits het via de band van het vennootschappelijk belang verloopt. Bestuurders op dochterniveau zullen vooral moeten waken voor het belang van de eigen vennootschap wanneer dit niet langer parallel loopt

van balans', $O \& F$ 2014/2, p. 5-23 waarnaar wordt verwezen in M. Olaerts, 'Herstructurering in concernverhoudingen: het vennootschappelijk belang, instructierechten en de autonomie van het bestuur van de dochtervennootschap', TvOB 2015/6, p. 228-238; A.J.M. Klein Wassink, 'Gedachten over de invulling van moederlijke zorgplichten in doorbraaksituaties', Ondernemingsrecht 2016/79.

${ }^{42}$ Hof Amsterdam (OK) 13 maart 2003, NJ 2003/248, JOR 2003/85, ro. 3.8.

${ }^{43} \mathrm{Zie}$ in die zin eveneens Hof Amsterdam (OK) 9 juli 2013, JAR 2013/223, m.nt. Zaal (Watts). Waarover eveneens S.M. Bartman, 'Hoge Raad weet zich niet goed raad met het concern', Onderneminsgrecht 2016/77.

${ }^{44}$ HR 26 oktober 2001, NJ 2002/94, m.nt. Ma, JOR 2002/2, m.nt. Bartman.

${ }^{45} \mathrm{Zie}$ in die zin eveneens onder meer D. Mokhberolsafa, 'Instructiebevoegdheid en de aansprakelijkheid van de moedervennootschap als medebeleidsbepaler van haar dochter-bv op grond van art. 2:248 lid 7 BW: een kwestie van balans', $O \& F$ 2014/2, p. 13. Mokhberolsafa gaat hierbij uit van een concernverhouding met een hechte concernstructuur. Zie voorts J.B. Huizink, Groene Serie Rechtspersonen 2013, aant. 11.6.

Huizink geeft in dit verband aan dat als bottom-line heeft te gelden dat het bestuur de instructies van de concernleiding niet mag opvolgen als dat ertoe zou leiden dat crediteuren niet meer voldaan kunnen worden. Hij geeft daarbij aan dat dit wel een erg magere invulling is van het vennootschappelijk belang maar dat als de vennootschap dreigt om te vallen, het vennootschappelijk belang en de voldoening van crediteuren dicht bij elkaar liggen. 
met het concernbelang en stakeholder benadeling voorzienbaar is. Het zal voor de bestuurder op dochterniveau niet altijd duidelijke zijn wanneer die grens is bereikt.

De concernleiding zal doorgaans het beste zicht hebben op de concernstrategie en het concernbelang. ${ }^{46}$ De kans bestaat dat het concernbelang sluipenderwijs de boventoon gaat voeren op dochterniveau en dat bestuurders van die dochter pas in een late fase in actie kunnen komen. Exemplarisch voor het feit dat het opofferen van het vennootschappelijk belang aan het concernbelang doorgaans gefaseerd verloopt, is de Kaal Masten-zaak die begin dit jaar voor de Ondernemingskamer werd gebracht. ${ }^{47}$ De bestuurder van een dochtervennootschap verzocht in die zaak de Ondernemingskamer een onderzoek te doen naar het beleid en de gang van zaken bij de eigen vennootschap. Volgens het bestuur ging het concernbeleid in tegen het beleid op dochterniveau. Nadat een deel van het concern in financieel moeilijk vaarwater terecht was gekomen, werd het concernbeleid aangescherpt. Op initiatief van de concernleiding werd voorts een aantal maatregelen genomen dat niet rechtstreeks in het belang was van de dochter. Ik ga hier niet verder in op de ins en outs van de zaak maar het gevolg van de maatregelen was onder meer dat de maandelijkse financieringslasten voor de dochter aanzienlijk toenamen. De Ondernemingskamer snelt het bestuur van de dochter niet te hulp. Volgens de Ondernemingskamer leidt de onderlinge verbondenheid tussen de concernvennootschappen ertoe dat die vennootschappen niet langer autonoom opereren. $\mathrm{Er}$ waren hoofdelijke aansprakelijkheidsverbanden jegens de bank en zekerheidsstellingen over en weer. Het is in een dergelijk geval volgens de Ondernemingskamer niet ongebruikelijk dat financiële krapte binnen het concern aanleiding geeft tot een scherper financieel beleid door de concernleiding. Van belang was onder meer dat de doorgevoerde maatregelen er niet toe hadden geleid dat de continuïteit van de dochter in gevaar kwam, ook speelde mee dat de dochtervennootschap in het verleden van het concernkrediet had kunnen profiteren. Kortom, in deze uitspraak wordt het voeren van de concernleiding gefaciliteerd. Net als in een goed huwelijk: de verbondenheid is er in goede en slechte tijden. Dat klinkt goed, maar voor het bestuur van de dochter zal niet eenvoudig kenbaar zijn wanneer de magere jaren erop zitten en de vette aanbreken. Lastig in zo een scenario is dat de continuïteit van de dochter meestal inderdaad niet acuut in gevaar zal zijn met als gevolg dat het bestuur van die dochtervennootschap knarsetandend moet toekijken hoe maatregelen worden genomen die op de langere termijn voor de dochter kostenverhogend werken en haar wel degelijk in de problemen kunnen brengen. Dat zal met name het geval zijn wanneer de huwelijkse voorwaarden niet vooraf duidelijk zijn besproken en de reikwijdte van het concernbelang binnen de groep en de mate van onderlinge verbondenheid niet vooraf duidelijk is.

\footnotetext{
${ }^{46}$ Zie over het feit dat de concernleiding het beste zicht heeft op maatregelen die genomen moeten worden om de financiële moeilijkheden binnen een concern als geheel het hoofd te bieden Hof Amsterdam (OK) 8 oktober 2013, RO 2014/28, JOR 2014/94 (Prins Dokkum BV) ro. 3.6.

${ }^{47}$ Hof Amsterdam (OK) 23 januari 2017, JOR 2017/96 m.nt. S.M. Bartman (Kaal Masten).
} 
Vooral wanneer het concern in financiële moeilijkheden verkeert, zullen het concern-en het vennootschappelijk belang twee kanten uitwijzen. Dan is het de vraag hoe de rechter achteraf de samenhang en de onderlinge verbondenbeid binnen het concern beoordeelt. Exemplarisch voor het feit dat dat niet altijd op eenduidige wijze gebeurt, is de Culi d'or zaak waarin rechtbank en hof tot een verschillende conclusie komen. ${ }^{48}$ Volgens de rechtbank kon de bestuurder aansprakelijk worden gesteld omdat ondernemingsactiviteiten van een dochter werden verkocht en de verkoopopbrengsten zonder zekerheidstelling werden doorgeleend aan andere concernonderdelen. Het hof komt echter tot een andere conclusie en kijkt voor de toelaatbaarheid naar de operationele en financiële verwevenheid tussen de verschillende concernonderdelen waarbij de activiteiten van de doorlenende vennootschap afhankelijk waren van de andere vennootschappen. Ook speelde mee dat nog kans was op herstel op het moment van het nemen van de maatregelen. Hoe nauwer de concernband, des te groter is de kans dat het vennootschappelijk belang daar onlosmakelijk mee samenhangt.

Kortom, de erkenning van het concernbelang is zeker geen nieuw fenomeen in het Nederlandse recht en valt goed in te passen mits het loopt via het vennootschappelijk belang en met inachtneming van het stakeholder model. Bij die erkenning van het concernbelang worden we echter nog met een aantal knelpunten geconfronteerd. Ik kan vandaag niet alle knelpunten bespreken maar noem er twee: de reikwijdte van de doorwerking van het concernbelang als inkleuring van het vennootschappelijk belang is niet altijd duidelijk en voor de bestuurders op dochterniveau zal niet altijd helder zijn wanneer de ondergrens is bereikt. De mate van verbondenheid (en eventuele machtsuitoefening) is in het huidige systeem van belang voor de toelaatbaarheid van de erkenning van het concernbelang maar dat zal niet altijd vooraf duidelijk zijn. Het blijft een zoektocht naar een evenwicht in de driehoek tussen verbondenheid, machtsuitoefening en de gevolgen daarvan voor de belangenafweging. De vraag daarbij is wanneer en of er een verschuiving in de belangenafweging moet plaatsvinden en wie daarvoor verantwoordelijk is: de concernleiding, het dochterbestuur of beiden. Wat is er nodig om de belangenafweging verder te verdelen? Is alleen verbondenheid voldoende om het concernbelang te laten doorwerken of moet ook sprake zijn van een verdergaande vorm van machtsuitoefening? Dat brengt mij bij de laatste vraag die ik vandaag aan de orde wil stellen namelijk: komt de oplossing vanuit Europese hoek of zijn er andere paden die we kunnen bewandelen? De aandachtige toehoorder zal aan deze suggestieve vraagstelling al gemerkt hebben dat ik in de richting van dat laatste neig.

\section{Europa of anderszins?}

\subsection{Europese aanpak?}

Een van de leidende gedachten bij de erkenning van het concernbelang op EU-niveau is het creëren van een safe harbour voor bestuurders van dochtervennootschappen. Gezocht wordt naar

\footnotetext{
${ }^{48}$ Hof 's-Gravenhage 18 augustus 2015, JIN 2015/199, m.nt. Wolf, r.o. 10 (Culi- d'Or).
} 
een test die bestuurders van de dochtervennootschap in staat stelt om de ondergrens, tot waar de erkenning van het concernbelang toelaatbaar is, handen en voeten te geven. Toegegeven, aangezien het bestuur op dochterniveau terecht dreigt te komen in een squeeze tussen concernleiding en de eigen wettelijke verplichtingen, lijkt zo een safe habour een waar bestuurlijk walhallah.

Ik heb daarbij echter een aantal bedenkingen waarvan ik er hier kort twee noem: 1 . In de eerste plaats vraag ik me af of het creëren van safe harbours de governance van het concern ten goede komt, volgens mij is dat laatste niet noodzakelijk het geval. 2. In de tweede plaats heb ik twijfels bij de haalbaarheid van het formuleren van een dergelijke uniforme test op EU-niveau gezien de bestaande nationale verschillen (dit komt in paragraaf 3.2 aan de orde).

Ik licht het eerste punt toe aan de hand van een voorstel dat geformuleerd is door de Informal Company Law Expert group. Voor het formuleren van een safe harbour stelt die groep voor om, naast een aantal andere voorstellen, een zogenaamde solvency test te introduceren. Die test moet gedaan worden door het bestuur van een $100 \%$ dochter op het moment waarop een besluit wordt genomen waarbij niet het eigen vennootschappelijk belang voorop staat maar het belang van de groep. ${ }^{49}$ Het bestuur van die dochter zou dan een verklaring moeten afleggen waaruit blijkt dat de vennootschap voor de daaropvolgende tijdspanne van minstens een half jaar aan haar verplichtingen zal kunnen voldoen. De door het bestuur van de dochter te maken belangenafweging wordt met andere woorden beperkt tot het doen van deze test. Ik ben geen voorstander van een dergelijke test. ${ }^{50}$ De rol van het dochterbestuur zou mijns inziens meer moeten omvatten dan enkel aangeven of de vennootschap de komende zes maanden aan haar verplichtingen zal kunnen voldoen. Het bestuur op dochterniveau kan binnen een stakeholderbenadering een belangrijke signaalfunctie vervullen. ${ }^{51}$ Het kan een noodzaak tot correctie of bijsturing van het concernbeleid bij de concernleiding signaleren waarbij haar rol met name gericht is op het waarborgen van de inbedding van het belang van de vennootschap op dochterniveau.

\footnotetext{
49 The informal Company Law Expert Group (ICLEG), Report on the recognition of the interest of the group, October 2016, p. 42. Dit is slechts een van de mogelijke voorstellen voor het verder uitwerken van de erkenning van het concernbelang zoals die door de Informal Expert Group zijn geformuleerd.

${ }^{50} \mathrm{Zie}$ voor andere voorstellen waarbij de taak van het bestuur op dochterniveau in ieder geval beperkt is, het voorstel van het Forum Europaeum met betrekking tot service companies, Forum Europaeum on Company Groups, 'Proposal to Facilitate the Management of Cross-Border Company Groups in Europe', ECFR 2015, p. 299-306. Ik kan hier niet op alle voorstellen en commentaren daarop ingaan maar verwijs voor kritische beschouwingen van dit voorstel naar het themanummer P. Hommelhoff, M. Lutter en C. Teichmann, Corporate Governance im Konzern, ZGR 2017/20.

${ }^{51} \mathrm{Zie}$ over het belang van een zorgvuldige besluitvorming waar zowel concernleiding als bestuur van de dochtervennootschap aan deelnemen C. Teichmann, 'Towards a European Framework for Cross-Border Group Management', $E C L$ 13, no. 5 2016, p. 156. Zie over het belang van het samenspel tussen de concernleiding en het bestuur op dochterniveau eveneens J.N. Druey, 'Gruppenrecht als Ausgleich- der Vorschlag des Forum Europaeum', ZGR 2017/20.
} 
Ik zie daarom meer heil in het bijstellen van de wijze waarop aan de aansprakelijkheid voor bestuurders zowel op dochter als op niveau van de concernleiding invulling wordt gegeven. ${ }^{52}$ (Op de invulling van aansprakelijkheid van de concernleiding, kom ik later terug nu eerst de kant van het dochterbestuur). Al eerder is in de literatuur gesignaleerd dat de erkenning van het concernbelang vooral in een top down richting in aanmerking wordt genomen en niet zozeer in de omgekeerde richting vanuit de positie van het dochterbestuur, ${ }^{53}$ dat zou mijns inziens wel moeten. Een wetswijziging is daarvoor niet nodig. De norm van het ernstig verwijt laat voldoende ruimte voor de rechter om met de concernrelatie rekening te houden. Daarbij zou voor de bestuurder op dochterniveau voorop moeten staan of zij op geïnformeerde wijze en met voldoende zorgvuldigheid de relevante belangen in kaart en bij de concernleiding onder de aandacht heeft gebracht. Het bestuur op dochterniveau moet daarbij voldoende door de concernleiding zijn geïnformeerd over het groepsbeleid en de mogelijke gevolgen van een bepaalde beslissing voor wat betreft de verdeling van baten en lasten over de groep. ${ }^{54}$

Tot zoverre de onderkant van het verhaal waarbij de positie van het bestuur op dochterniveau centraal staat. De erkenning van het concernbelang heeft uiteraard ook een andere kant namelijk de top down benadering waarbij de vraag kan worden gesteld in welke gevallen het concernbelang maatgevend mag zijn, met andere woorden: hoe hecht moet het concernverband zijn en wat zijn de consequenties van het vooropstellen van dat concernbelang door de concernleiding.

Ik wees al op het bestaan van een concernleidingsplicht in het Nederlandse systeem en ik gaf ook al aan dat binnen een hechte concernstructuur de moedervennootschap als consequentie van haar machtsuitoefening een zorgplicht kan hebben ten opzichte van de schuldeisers van haar dochter. Voor het duiden van de hechtheid van het concernverband op Europees niveau blijkt uit de verschillende voorstellen van de werkgroepen door de jaren heen een grote attractiviteit uit te gaan van de in de Franse jurisprudentie ontwikkelde Rozenblum doctrine. ${ }^{55}$ Volgens die

\footnotetext{
${ }^{52}$ Zie in die zin eveneens C. Teichmann, 'Towards a European Framework for Cross-Border Group Management', ECL 13, no. 5, 2016, p. 153-154.

${ }^{53}$ S.M. Bartman 'Hoge Raad weet zich niet goed raad met het concern', Ondernemingsrecht 2016/77.

${ }^{54} \mathrm{Zie}$ in vergelijkbare zin C. Teichmann, 'Towards a European Framework for Cross-Border Group Management', ECL 13, no. 5, 2016, p. 156.

${ }^{55} \mathrm{Zie}$ hierover Report of the Reflection Group on the Future of EU Company Law, April 2011, p. 63; ICLEG, Report on the recognition of the interest of the group, October 2016, p. 23 e.v. Volgens de Reflection group heeft de Rozenblum doctrine of een variant daarop zich ontwikkeld tot een ius commune in de lidstaten die het concernbelang erkennen. De EMCA gaat uit van een vereenvoudigde versie van deze doctrine omwille van de onduidelijkheid waarmee deze is omgeven zie hoofdstuk 15 section 16 en de toelichting p. 485; Zie over deze aanpak P.H. Conac, 'Director's Duties in Groups of Companies- Legalizing the Interest of the Group at the European Level', ECFR 2013, p. 216. Zie voorts de voorstellen van het Forum Europaeum on Company Groups, 'Proposal to Facilitate the Management of Cross-Border Company Groups in Europe', ECFR 2015, p. 299-306 waarbij eveneens wordt geput uit de Franse doctrine. Verschillende landen hebben inspiratie gezocht in deze doctrine voor wat betreft hun nationale regeling zoals bijvoorbeeld Italië en Tsjechië, zie hierover M. Winner, 'Group Interest in European Company Law: an Overview', Acta Univ. Sapientiae, Legal Studies, 5, 1 (2016) 85-96 en de European Model Companies Act, p. 372. Daarnaast zijn er ook andere, deels flankerende voorstellen gedaan zoals het leggen van een grotere verantwoordelijkheid bij de concernleiding. In de EMCA wordt bijvoorbeeld
} 
doctrine ${ }^{56}$ mag het concernbelang voorop worden gesteld wanneer aan een aantal voorwaarden is voldaan waaronder: het bestaan van juridische en financiële links tussen de verschillende groepsvennootschappen, het hebben van een duidelijke concernstructuur waarin de onderneming is geïntegreerd, een evenredige verdeling van voor- en nadelen binnen de groep. Daarnaast mag het dienen van het groepsbelang niet leiden tot de ondergang van de (dochter)vennootschap. ${ }^{57}$ Vrij vertaald naar de driehoekverhouding tussen verbondenheid, macht en belangenafweging impliceert dit dat wanneer de machtsuitoefening zo groot is geweest dat hierdoor een vergaande mate van verbondenheid wordt bereikt, dan is het vooral aan de concernleiding om de belangen af te wegen. De belangenafweging die van de dochtervennootschap wordt verwacht is beperkt. De gedachte is dat die Rozenblum doctrine in landen waarin het concernbelang wordt erkend inmiddels is verworden tot een zogenaamd Ius Commune waardoor overeenstemming tussen de lidstaten binnen handbereik ligt.

Ik plaats daar vraagtekens bij. Die vraagtekens plaats ik overigens niet bij het feit dat een min of meer vergelijkbaar systeem in de verschillende lidstaten boven lijkt te drijven. Ik vraag mij wel af of nationale regelgevers en de rechterlijke macht bereid en in staat zullen zijn om hun zorgvuldig opgebouwde nationale systeem met de daarbij behorende nuanceverschillen los te laten of anders in te vullen. ${ }^{58}$ De Nederlandse doorbraak jurisprudentie heeft zich door de jaren heen bijvoorbeeld ontwikkeld tot een complex systeem van do's en dont's in concernverhoudingen. Het nadeel van actie op Europees niveau is bovendien dat het een langerekt proces is en uiteindelijk kan resulteren in vrij algemene bepalingen die wellicht weinig houvast bieden. ${ }^{59}$ Maar daarmee wil ik zeker niet gezegd hebben dat de Europese ontwikkelingen nutteloos zijn. Ik heb alleen wat voorzichtige bedenkingen geplaatst bij de

voorgesteld om een zogenaamde wrongful trading rule op concernniveau te introduceren waarbij van de concernleiding wordt verwacht dat deze zal ingrijpen wanneer een dochtervennootschap die onder haar instructie staat in financiële moeilijkheden komt te verkeren. Zie hoofdstuk 15, section 17 EMCA.

${ }^{56}$ Cass. Crim., 4 februari 1985, Bull. Crim. Nr. 54, JCP G, 1986, II, p. 20585.

${ }^{57} \mathrm{Zie}$ in deze zin het rapport van de Reflection Group on the Future of EU Company Law uit 2011 , p. 62 te raadplegen via ssrn. De voorwaarden van de Rozenblum-doctrine worden overigens in de literatuur op verschillende wijzen weergegeven. De reflection group vertaalt de eerste voorwaarde met de Engelse term 'capital links'. De Club des Juriste heeft het bijvoorbeeld over 'legal and financial links' tussen de vennootschappen. De reflection group verwijst bijvoorbeeld naar de volgende voorwaarden: 'First, there must be a group characterized by capital links between the companies. Second, there must be strong, effective business integration among the companies within the group. Third, the financial support from one company to another company must have an economic quid pro quo and may not break the balance of mutual commitments between the concerned companies. Fourth, the support from the company must not exceed its possibilities. In other words, it should not create a risk of bankruptcy for the company.' De Club des Juristes omschrijft die eerste twee voorwaarden bijvoorbeeld als volgt: 'there must be a group: the legal and financial links among the companies of the group must be demontrated, as well as the implementation of a common strategy aiming at the realisation of a common project; the operation must originate in a common economic, social or financial interest, which is to be assessed in relation to a policy that has been elaborated for the whole group (...).' Rapport van de Club des juristes, Report Towards Recognition of the Group Interest in the European Union, juni 2015, p. 16-17.

${ }^{58}$ Overigens gaan in de literatuur ook stemmen op om een afzonderlijk model voor grensoverschrijdende groepen te introduceren naast de bestaande nationale systemen zie hierover G. Franzmann, 'Europäisches Konzernrecht: Vom Gesellschaftsschutzrecht zum Enabling Law für Unternehmen', ZGR 2017/20.

${ }^{59} \mathrm{Ik}$ denk hierbij bijvoorbeeld aan het sterke compromis karakter van de Europese overnamerichtlijn of het systeem van de Societas Europea, dat laatste heeft overigens meer dan 40 jaar nodig gehad om het levenslicht te zien. 
mogelijke uitvoering en zie nog wat obstakels voordat het zover is. Ik denk dat we juist het Europese debat moeten gebruiken om zelf aan de slag te gaan in de tussentijd. Daarbij behoort ook het nader invulling geven aan de verwachtingen die aan de concernleiding worden gesteld en het verder bijstellen van een aansprakelijkheidsnorm op niveau van het bestuur van de concernleiding en op dochterniveau die daarmee rekening houdt. ${ }^{60}$ Dat kan mijns inziens niet zonder dat we het onderliggende probleem aanpakken namelijk: in plaats van achteraf oordelen, vooraf duidelijker maken wat van een goede concern governance wordt verwacht.

\subsection{Anderszins: een duale aanpak}

Mijn idee is dat we beter kunnen kiezen voor een duale aanpak. Daarbij moeten we vooral doorgaan met de gedachtevorming op Europees niveau. Het debat op Europees niveau en de verschillende werkgroepen die zich hierover hebben gebogen, door nationale systemen te vergelijken en te komen tot een nadere concretisering, leveren ontegenzeggelijk een belangrijke bijdrage aan de rechtsontwikkeling op dit punt. Maar daartoe mogen we het niet beperken. Ook op nationaal niveau kan nog verdere vooruitgang worden geboekt.

Een mogelijke weg vooruit is naar mijn mening gelegen in het verschaffen van meer inzicht in het bestaande nationale systeem om op die manier bij te dragen aan bottom up harmonisatie. Dat kan volgens mij worden bereikt door het opstellen van een framework of code voor governance in concernverhoudingen. ${ }^{61}$ Als we concernmanagement willen faciliteren, dan moeten we inzichtelijk maken wat dat kan inhouden.

De termen verbondenheid en macht zouden daarin nader moeten worden uitgewerkt waarbij denkbaar is dat er zich verschillende vormen en gradaties van verbondenheid en machtsuitoefening kunnen voordoen. Dat zien we intussen ook terugkomen in het Nederlandse systeem. De verbondenheid op zich creëert al een aantal verplichtingen. De verbondenheid kan aanleiding geven tot een concernleidingsplicht. Verbondenheid biedt daarnaast ook de mogelijkheid om macht uit te oefenen. Die machtsuitoefening kan in verschillende gradaties plaatsvinden: van een dochtervennootschap die vrij autonoom opereert tot een dochtermaatschappij met activiteiten die instrumenteel zijn aan de activiteiten van de moeder en de rest van de groep. Echter, niet in alle gevallen waarin sprake is van een concernleidingsplicht, zal ook sprake zijn van een zorgplicht ten opzichte van de dochtervennootschap en haar schuldeisers zoals aangenomen in de doorbraakjurisprudentie. Daarvoor is een verdergaande vorm van machtsuitoefening nodig. In de traditionele benadering lijken de verplichtingen echter wel toe te nemen naarmate de machtsuitoefening groter wordt.

\footnotetext{
${ }^{60}$ In die zin eveneens C. Teichmann, 'Towards a European Framework for Cross-Border Group Management', ECL 13 , no. 5, 2016, p. 153-154.

${ }^{61}$ Als ik het goed begrijp, is dit eveneens in zekere zin voorgesteld door Conac. Zie P.H. Conac, 'Director`s Duties in Groups of Companies- Legalizing the Interest of the Group at the European Level', ECFR 2013, p. 216. Conac ziet dit meer als een taak van de Europese Commissie bij het formuleren van een richtlijn of aanbevelingen waarbij ze een code of conduct zouden kunnen opstellen van 'good and poor practices'.
} 
Binnen het framework kan een onderscheid worden gemaakt tussen verschillende manieren waarop aan de concerngovernance invulling wordt gegeven waarbij het concernbelang, afhankelijk van de onderlinge verbondenheid en machtsuitoefening robuuster kan worden. De gradaties in de machtsuitoefening kunnen daarbij nader worden geduid. De verplichtingen van de concernleiding om met de belangen op dochterniveau rekening te houden nemen dan verhoudingsgewijs toe.

Aandacht moet daarbij ook worden besteed aan de concerninterne verhoudingen en het creëren van meer transparantie ten aanzien van de invulling van die interne verhoudingen. ${ }^{62} \mathrm{Nu}$ de nadruk in het verleden vooral heeft gelegen op het voorkomen van risico`s en het leggen van een verantwoordelijkheid top down bij de concernleiding, is het tijd voor een aanpak waarbij meer aandacht wordt besteed aan het op verantwoorde wijze managen van het concern als geheel waarbij de nadruk niet zozeer ligt op het voorkomen van risico`s die de concernstructuur met zich brengt en het bestraffen van het gebruik van macht met aansprakelijkheid maar veeleer op het expliciteren van inzichten ten aanzien van het op verantwoorde wijze managen van het concern als geheel. Het Europese debat over de erkenning van het concernbelang kan hier dienst doen als vliegwiel voor verandering. De gedachte om via de erkenning van het concernbelang concernmanagement te vereenvoudigen waarbij de nadruk ligt op het faciliteren van het voeren van een concernleiding en niet zozeer op het reguleren van concernverhoudingen teneinde misbruik te voorkomen, biedt mijns inziens een mogelijkheid en een noodzaak om het concern ook in het Nederlandse recht op een andere wijze te benaderen. Daarbij zou meer duidelijkheid moeten komen ten aanzien van de Nederlandse maatstaven van goede concern governance. ${ }^{63} \mathrm{De}$ huidige corporate governance code is uiteraard ook van toepassing op concernverhoudingen maar aan de interne concernverhouding wordt daarin weinig aandacht besteed. Een inventarisatie moet worden gemaakt van best practices binnen concernverhoudingen. Een ontwikkeling waarbij aandacht wordt besteed aan governance in concerns is ook terug te vinden in de bankenwereld. ${ }^{64}$

\footnotetext{
${ }^{62}$ Te denken valt in dit verband zoals Teichmann aangeeft, dat vooraf wordt duidelijk gemaakt dat de dochtervennootschap aan instructies van de concernleiding onderworpen is. C. Teichmann, 'Towards a European Framework for Cross-Border Group Management', ECL 13, no. 5, 2016, p. 156. Het Forum Europaeum gaat bij ordinary companies ook uit van een systeem waarbij er een duidelijke groepsstrategie moet zijn Forum Europaeum on Company Groups: 'Proposal to Facilitate the Management of Cross-Border company Groups in Europe', ECFR 2015 , p. 304.

${ }^{63} \mathrm{Zie}$ over corporate governance in het concern het themanummer P. Hommelhoff, M. Lutter en C. Teichmann, Corporate Governance im Konzern, ZGR 2017/20.

${ }^{64}$ Zie bijvoorbeeld Richtlijn 2014/59/EU van het Europees Parlement en de Raad van 15 mei 2014 betreffende de totstandbrenging van een kader voor het herstel en de afwikkeling van kredietinstellingen en beleggingsondernemingen en tot wijziging van Richtlijn 82/891/EEG van de Raad en de Richtlijnen 2001/24/EG, 2002/47/EG, 2004/25/EG, 2005/56/EG, 2007/36/EG, 2011/35/EU, 2012/30/EU en 2013/36/EU en de Verordeningen (EU) nr. 1093/2010 en (EU) nr. 648/2012, van het Europees Parlement en de Raad die het voor banken die onderdeel uitmaken van een groep mogelijk maakt om in tijden van nood andere groepsmaatschappijen financieel te ondersteunen. De corporate governance principes voor banken bevatten een bepaling voor governance binnen concern Basel Committee on Banking Supervision Guidelines, Corporate governance principles for banks, July 2015, principe 5. Binnen de verzekeringswereld wordt hier eveneens aandacht aan besteed zo getuige onder meer het issues paper uit 2014 van de International Association of Insurance Supervisors (IAIS) over corporate governance van groepen. IAIS, Issues Paper, Approaches to Group Corporate Governance; Impact on Control Functions,
} 
Uiteraard spelen daar andere belangen en een andere dynamiek waardoor de bepalingen niet één op één kunnen worden overgenomen. Ik denk aan publieke belangen en flankerende regelgeving en betrokkenheid van verschillende toezichthouders. In de nadruk die in het Europese debat wordt gelegd op de Rozenblum doctrine en op het creëren van meer transparantie in concernverhoudingen zie ik hoop voor een duidelijker uitgestippeld concernbeleid. Dat kan bestuurders op dochterniveau binnen een concern waarin gekozen is voor meer autonomie op dochterniveau helpen om meer inzicht te krijgen in het concernbeleid en de genoemde huwelijkse voorwaarden.

Het opstellen van een dergelijk framework heeft een aantal voordelen. Zowel de concernleiding als het bestuur op dochterniveau zou duidelijkere handvaten geboden kunnen worden ten aanzien van de belangenafweging die van hen wordt verwacht. Daarbij kan rekening worden gehouden met de gewenste flexibiliteit in de interne inrichting van het concern en met de grote diversiteit in concernverhoudingen. Afwijkingen of aanpassingen moeten toegestaan zijn wanneer de aard van de onderneming of het gekozen samenwerkingsverband daar aanleiding toe geven. ${ }^{65}$ Bovendien zou door middel van een dergelijke aanpak zowel voor het bestuur op dochterniveau als naar derden toe meer transparantie kunnen worden betracht ten aanzien van de gewenste hechtheid van de concernstructuur. Anders dan de huidige ex post kwalificatie van het concern in de rechtspraak, zou vooraf door de concernleiding reeds in onderling overleg met het bestuur op dochterniveau gesproken kunnen worden over de gewenste hechtheid van het concernverband en wat dit onder omstandigheden kan inhouden. Daarbij kan de concernleiding uitdrukking geven aan de haar voorgestane evenredige verdeling van baten en lasten over het concern. Het zou een duidelijker concernbeleid in de hand kunnen werken. Het bestuur op dochterniveau wordt daarmee meer inzicht geboden in de evenredige verdeling van lusten en lasten over het concern. Wanneer het bestuur op dochterniveau gevraagd wordt om tijdelijk haar eigen noden opzij te schuiven ten behoeve van haar zustervennootschappen of het concern als geheel, kan dit in de overweging worden meegenomen. Teneinde de concernleiding te beschermen, gaan in de literatuur stemmen op voor het introduceren van een business judgement rule op concernniveau. Teichmann stelt bijvoorbeeld voor de marginale toetsing van bestuurshandelen zoals die in sommige landen geldt binnen individuele vennootschappen ook toe te passen op concernniveau. ${ }^{66}$ Zolang sprake is van een coherent en transparant concernbeleid en een deugdelijke besluitvorming, zouden bestuurders zijns inziens een beroep moeten kunnen doen op

oktober 2014. Zie hierover en over de banking supervision guidelines ICLEG, Report on the Recognition of the Group Interest, Oktober 2016, p. 11.

${ }^{65}$ Daarbij kan gebruik worden gemaakt, zoals onder meer ook Conac voorstelt, van het comply or explain principe. P.H. Conac, 'Director's Duties in Groups of Companies- Legalizing the Interest of the Group at the European Level', ECFR 2013, p. 216.

${ }^{66}$ C. Teichmann, 'Towards a European Framework for Cross-Border Group Management', ECL 13, no. 5 2016, p. 156. 
deze 'group-related business judgment rule'. ${ }^{67}$ De best practices zouden dienst kunnen doen bij het vormgeven van een dergelijk coherent concernbeleid.

Ik zie u denken, zou een dergelijke aanpak niet leiden tot een te strak keurslijf? Toegegeven, een verdere definiëring kan de bestaande flexibiliteit inperken. Niet uit te sluiten is dat de framework bepalingen bijvoorbeeld in de rechtspraak worden gebruikt om te bezien of de concernleiding of het bestuurder op dochterniveau iets te verwijten valt. Desalniettemin, biedt het feit dat het gaat om de invulling van open normen zoals het vennootschappelijk en het concernbelang de mogelijkheid om ook in de toekomst rekening te houden met de omstandigheden van het geval. Uiteraard zullen ook niet alle typen concernverhoudingen kunnen worden afgedekt en dat is ook niet de bedoeling. Is daarmee het Europese probleem in de grensoverschrijdende concernverhoudingen opgelost? Uiteraard niet, maar zo wordt voor buitenlandse partijen wel duidelijk welke verwachtingen in Nederland bestaan ten aanzien van de concernleiding en kan gaandeweg een zogenaamde 'soft harmonisatie' tot stand worden gebracht. ${ }^{68}$

Dit brengt me bij het laatste deel van mijn oratie: de toekomstplannen.

4. Future outlooks

Ladies and gentlemen, as promised at the end of this inaugural lecture I turn to English to devote a few words to future outlooks with regard to today`s topic as well as my research and teaching ambitions.

I have only been able to touch upon a few issues which raise my interest and require further development. The reason for choosing this topic is because in many ways it reflects several future challenges in company law more broadly. I plan to further research some of these challenges within the ambit of the Institute for Corporate Law, Governance and Innovation Policies (ICGI) and will name some of them here as part of the future research agenda:

One of the main challenges concerns the way in which behavior of corporations and its main actors can be regulated.

This can be divided into several aspects such as the question touched upon today as to at which level a certain issue should be regulated: national or European and how harmonization can be achieved. The EU recognition of the group interest reflects an interesting path in this respect. Instead of imposing top down regulation at the EU level, the debate concerning the recognition of the group interest strives to use the existing ius commune as a point of departure.

\footnotetext{
${ }^{67} \mathrm{Zie}$ voorts A.J.M. Klein Wassink, 'Gedachten over de invulling van moederlijke zorgplichten in doorbraaksituaties', Ondernemingsrecht 2016/79 die voor wat betreft het Nederlandse recht van mening is dat voor aansprakelijkheid van de concernleiding maatgevend zou moeten zijn of hen in de aansturing van het concern een ernstig verwijt kan worden gemaakt.

${ }^{68} \mathrm{Zie}$ hierover ICLEG, Report on the Recognition of the Group Interest, Oktober 2016, p. 30 waarin de verwachting wordt uitgesproken dat de erkenning van het concernbelang zal leiden tot een soft harmonisatie.
} 
But there is more in terms of types of regulation. Corporate actors are increasingly regulated by sector specific laws think of specific rules in the banking, the insurance as well as the health care sector. All of these developments pose interesting challenges for the future of our company law and will have an influence on the role of corporate actors. This also links in with the role of courts in this changing regulatory environment. It was already pointed out by colleague Assink ${ }^{69}$ in his inaugural lecture that judiciaries increasingly take up an important role and that one of the challenges for the future will be how to deal with this role in a responsible manner. Courts are increasingly confronted with questions on how to deal with different types of regulation, think of soft law, self-regulation but also sector specific rules which all have an influence on the corporate environment.

These research topics have many links with other disciplines and within the ambit of this chair I plan to intensify the already existing cooperation between the institute and other institutes inside and outside of our faculty as well as with corporate practice. Looking at an issue from various disciplines helps to create a holistic view and to design the way forward.

I also plan to use this broad view in teaching. Teaching is so much more than making sure students know every aspect of the law. It is about inspiring and allowing yourself to be inspired by others. .. it is about experimenting with teaching methods and team building. It is also enabling students to see the broad spectrum of regulations and its impact on society at large. During the first weeks of the corporate social responsibility course students often find it hard to grasp the subject as they say it is not 'legal enough'. However, our regulatory environment is changing and we have to prepare our students by exposing them to this broad spectrum and its varieties of regulation.

Dear all, as I am approaching the end of the content related part of this lecture, let me return to the elephant.

There is an old parable about an elephant in the dark. There seem to be many versions of the story around but what it boils down to is that several people are placed in a dark room with an elephant. Not knowing what the object in the room is, they all feel different sides of the animal. When they come out of the room, they tell each other what they think they have felt but they cannot seem to come to an agreement. In many ways this is comparable to company groups. Company groups are large and difficult to pinpoint, they are looked at increasingly from various perspectives and disciplines. Various methods are used to regulate these structures from soft law norms to legal presumptions and risk based liability. It will not be possible nor necessary to come up with one harmonized approach. However, it is important to look at these different

\footnotetext{
${ }^{69}$ B.F. Assink, De januskop van het ondernemingsrecht. Over faciliëring en regulering van het ondernemingsrecht, (oratie Rotterdam) Kluwer: Deventer 2010.
} 
views, the underlying ideas and at their influence on the internal functioning of groups in order to gain a more overall and coherent picture. ${ }^{70}$

And this brings me to the very last part for which I will address those who are dear to me in my mother tongue.

Dank ben ik verschuldigd aan het college van bestuur van de Universiteit Maastricht en de faculteit der rechtsgeleerdheid voor het in mij gestelde vertrouwen. Ik ben bijzonder verheugd dat ik aan deze mooie universiteit invulling mag geven aan een leerstoel.

Ik dank Hildegard Schneider, René de Groot en Jan Smits voor de hartelijkheid en steun die ik door de jaren heen van hen heb mogen ervaren.

Buitengewoon veel plezier beleef ik dagelijks aan de samenwerking met de medewerkers van het ICGI en de vakgroep privaatrecht. Het zijn er te veel om op te noemen maar jullie zijn mij evenals de medewerkers van het secretariaat zeer dierbaar. Daartoe behoren ook de promovendi die ik mag begeleiden en heb begeleid. Jullie dank ik voor de openheid en het vertrouwen dat jullie mij schenken waardoor ik deelgenoot word van jullie reis door het vakgebied met alle highs en lows die daarbij horen.

Steef Bartman en Adriaan Dorresteijn ook jullie wil ik van harte danken voor de steun die ik al vele jaren mag ervaren. Ik heb met bijzonder veel plezier samengewerkt aan het boek Van het concern.

Hetzelfde plezier waarmee ik in Maastricht door het faculteitsgebouw loop, mag ik sinds enige tijd ervaren in Den Haag bij DVDW Advocaten. Jullie hebben mij op buitengewoon hartelijke wijze in jullie midden opgenomen. Bijzondere dank gaat daarbij uit naar Theo Hanssen die de initiële contacten tussen DVDW en het ICGI tot stand bracht en mij lange tijd als kamergenoot heeft getolereerd.

In het bijzonder noem ik aan Maastrichtse zijde nog Christine van Basten Boddin, mijn persoonlijke steun en toeverlaat die zo nodig burgemeester moest worden. Je coachende manier van samenwerken is een belangrijke inspiratiebron voor mij. Bijzonder veel dank gaat ook uit naar Bas Steins Bisschop, Sybren de Hoo en Jan Eijsbouts al jaren werk ik op een erg prettige manier met jullie samen en jullie staan samen met Christine en Kid aan de basis van het mooie instituut waar ik in verder mag gaan. Ton Hartlief en Jos Hamers, jullie weten het altijd gezellig te maken daarboven op onze in het 'geheim' aan elkaar gelinkte studeerkamers op de rechtenfaculteit. Ik dank jullie voor de dagdagelijkse gezelligheid maar bovenal voor jullie steun. En dan uiteraard Kid Schwarz, een van mijn oud promotores, voorganger, inspirator en roerganger. Dank je wel voor het aanbrengen van de relativerende noot.

\footnotetext{
${ }^{70}$ See about the differences in rules applicable to company groups H. Fleischer, 'Europäisches Konzernrecht: Eine akteurzentrierte Annäherung', ZGR 2017, p. 2-36.
} 
Via deze mensen die mij erg dierbaar zijn, begeef ik me in de vriendschappelijke en familiale sfeer:

Mieke, Janneke, Susan, Bea en Jamie jullie behoren al jaren tot de harde kern. Ik dank jullie voor jullie aanhoudende vriendschap en betrokkenheid in goede en slechte tijden, doorheen alle levensfases: soms ver weg door de hectiek van het leven of de waan van de dag maar in gevoel en gedachte altijd zó dichtbij.

En dan mijn ouders:

Papa: een van de grootste cadeaus in het leven: een ontembare levenslust, die heb ik van u. Dat het leven dient om van te genieten is iets dat ik dagelijks in me draag ook al is dat voor u niet altijd zichtbaar als ik weer eens boven de boeken hang. Toch zit het in mijn DNA en beloof ik u plechtig (hoewel ik het soms tijdelijk verwaarloos) het nooit te zullen vergeten. Ik stel voor dat we de rest van de dag doorbrengen in het teken van uw levensfilosofie, die ik zonder meer graag tot de mijne maak...

Mama: ik dank u voor uw onvoorwaardelijk steun en vastberadenheid om in alles er altijd voor mij te zijn. Er zijn geen grenzen en één blik is voor u genoeg om te weten wat in mij omgaat.

En dan kom ik bij Frank, samenleven met mij is niet altijd eenvoudig. De gemoedstoestand wil wel eens afhangen van de stand van het onderzoek of de kwaliteit van een pas gelezen werkstuk. Ik dank je om hierin mee te deinen, voor je steun en het geduld. De lieve woorden en de adviezen die ik soms (misschien herhaaldelijk) in de wind sla. Ook je ouders, Jacqueline en Henk wil ik bedanken omdat zij mij hebben laten zien hoe het is om van een groot gezien onderdeel uit te maken.

Helaas zijn er ook mensen die vandaag niet meer aanwezig kunnen zijn zoals mijn beide grootvaders maar ik ben bijzonder verheugd dat hier op de eerste rij mijn beide grootmoeders zitting hebben genomen. Zij zijn vandaag mijn eregasten.

Ik heb gezegd! 